\title{
The Cycle of Development in Africa: A Story about the Power of Economic Ideas
}

\author{
Martin PALdAM ${ }^{\mathrm{a}}$
}

JEL-Classification: O11, O55

Keywords: Africa, development policy, institutions

\section{Introduction}

This essay deals with the economic development of Africa, which is taken to mean Sub-Sahara Africa. 44 countries on the continent are considered. It is assumed that they have so much in common that it makes sense to treat their development as a set of variations around a joint African path. This path has three distinct phases shown in Figures 1 and 6 below: (P1) From the start of the data in 1950 to 1972 growth was decent. (P2) From 1973 till 1993 growth was negative. (P3) Since 1994 decent growth has resumed. This cyclical picture is clear in the data for 32 of the countries while 3 countries have a clearly different path. The last 9 countries follow the cycle for 1-2 periods, but not fully.

Due to the negative growth in P2, the level from the end of P1 was only reached in 2004, so Africa had 20 years of falling GDP per capita and 30 years of zero economic growth. About 16 countries of the world have a GDP per capita that is lower today than in 1950. Of these no less than 12 are African. These facts have been known as Africa's growth tragedy since EAsterly and Levine (1997).

This essay concentrates on the cyclical paths, but section 3 also considers the low underlying long-run growth rate. The paper does not bring econometric tests, though it refers to a number of econometric papers. I have searched the literature and found 11 theories that have been used to explain development of Africa. Each theory is confronted with the African cycle of P1-P3, by asking if the most relevant variable representing the theory has a similar cycle. 11 theories are a lot to cover, and the data are often incomplete. However, it appears that only one of the theories fits the facts. The cycle of development in Africa follows the big shifts in development strategy. Consequently, if one of the theories is true, it

a Department of Economics and Business, Aarhus University, 8000 Aarhus C, Denmark. E-mail: mpaldam@econ.au.dk, URL: http://www.martin.paldam.dk. 
is that the cycle is caused by the shifts in development strategy, corresponding to changes in the dominating sets of economic ideas in Africa and among the many development economists advocating these ideas. Thus, it is a story about the power of economics.

The paper proceeds as follows. Section 2 looks at the data to show what has to be explained. Section 3 looks into the textbooks of economic theory for a general explanation. It discusses three theories most economists automatically reach for when they try to explain the development of Africa. Section 4 considers five specific theories developed to explain period P2, the growth tragedy, and two additional theories that are supposed to apply to all three periods. These theories are all found to be empirically problematic. Section 5 looks at the only theory that is in accordance with the data. Section 6 concludes.

\section{What Has to Be Explained?}

The analysis uses the MadDison (2003) data set as updated to 2008. ${ }^{1}$ It reports complete time series starting in 1950 for 44 countries. ${ }^{2}$ The appendix lists the countries and brings a few descriptive statistics. The paper looks at national accounts data in real PPP prices. When GDP is written $g d p$ (with small letters) it is per capita. Income is ln gdp, the natural logarithm to GDP per capita. The growth rate is always based on the gdp-series.

\subsection{The Path and the Three Periods: P1, P2 and P3}

The path of the 44 African countries is shown in Figure 1. It is compared with the path for the average Western countries and 74 Other countries, which are all other countries in the Maddison set with complete series. The three periods - P1, P2 and P3 - from the introduction are indicated by the vertical lines.

Table 1 summarizes the information in Figure 1. The averages in P1 and P3 do not differ significantly, but growth in P2 is significantly different. While the downswing from P1 to P2 is relatively large in Africa, so is the upswing from P2 to P3.

1 National accounts for many African countries are weak and some have gaps or jumps. The paper does not discuss how the series are joined up, but take the data for granted.

2 The only country I would have included if data had not been missing is Eritrea. By choice Mauritius, the Seychelles and South Africa, are excluded. However, South Africa follows the cycle perfectly well. 
Figure 1: The Growth Path of Income for Three Country Groups, 1950-2010

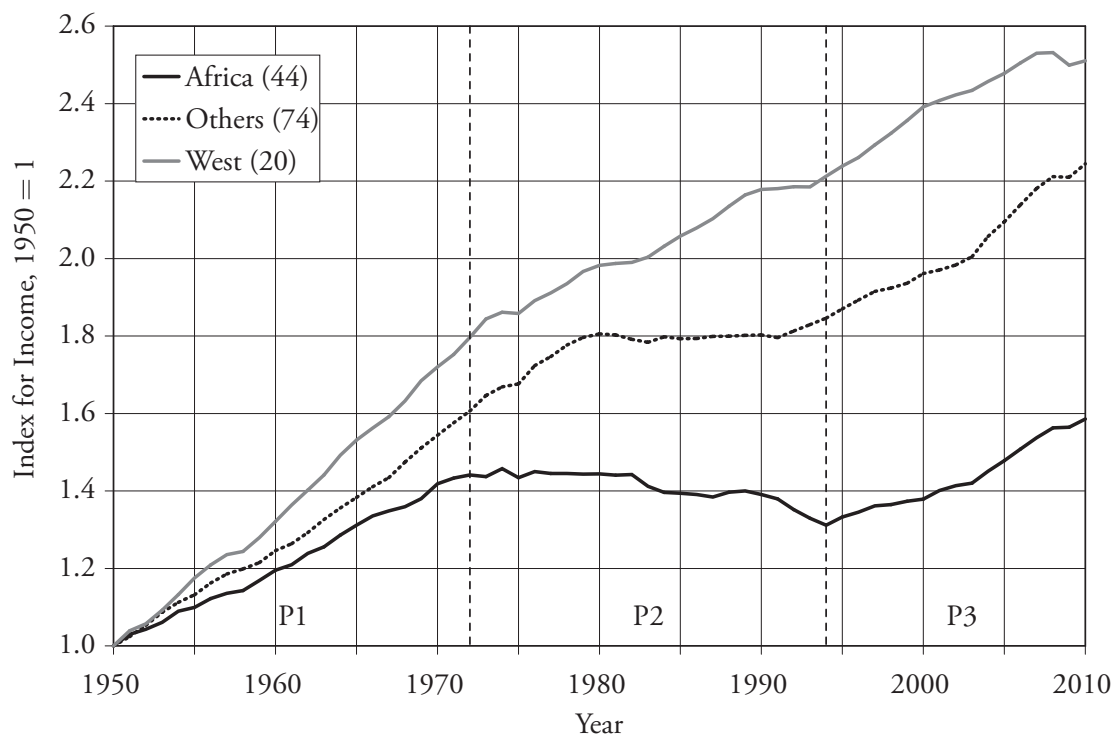

Note: The calculations cover 44 African, 20 Western countries and 74 Others, which are all countries with data for all years. The data for the last 2 years are from the CIA Factbook and not fully comparable. They are not used except on Figures 1,2 and 6.

Source: Maddison (2003).

Table 1: Average Growth Rates for 1950-2008

\begin{tabular}{|c|c|c|c|c|c|c|c|c|c|}
\hline \multirow[t]{2}{*}{ Group } & \multirow[t]{2}{*}{ Countries } & \multicolumn{2}{|c|}{ Growth all years } & \multicolumn{3}{|c|}{ The three periods } & \multicolumn{2}{|c|}{ Change } & \multirow{2}{*}{$\begin{array}{l}\mathrm{N} \text { for all } \\
\text { periods }\end{array}$} \\
\hline & & Per year & Times & P1 & P2 & P3 & $\Delta \mathrm{P} 2$ & $\Delta \mathrm{P} 2$ & \\
\hline Africa & 44 & $\begin{array}{c}1.16 \\
(0.24)\end{array}$ & 2.0 & $\begin{array}{c}2.14 \\
(0.31)\end{array}$ & $\begin{array}{c}-0.30 \\
(0.44)\end{array}$ & $\begin{array}{c}1.77 \\
(0.51)\end{array}$ & -2.44 & 2.07 & 2552 \\
\hline Others & 74 & $\begin{array}{c}2.29 \\
(0.18)\end{array}$ & 3.9 & $\begin{array}{c}2.98 \\
(0.29)\end{array}$ & $\begin{array}{c}1.24 \\
(0.32)\end{array}$ & $\begin{array}{c}2.73 \\
(0.28)\end{array}$ & -1.74 & 1.49 & 4292 \\
\hline West & 20 & $\begin{array}{c}2.71 \\
(0.15)\end{array}$ & 5.0 & $\begin{array}{c}3.72 \\
(0.26)\end{array}$ & $\begin{array}{c}1.90 \\
(0.23)\end{array}$ & $\begin{array}{c}2.35 \\
(0.20)\end{array}$ & -1.82 & 0.46 & 1160 \\
\hline
\end{tabular}

Note: Calculations for all 138 countries with full series 1950 to 2008. Growth is in per cent of gdp, changes are in percentage points, and brackets report 2 standard errors.

Source: Maddison (2003). 


\subsection{The Underlying Political Dynamics of Economic Ideology/Development Strategy}

The most obvious explanation of the cyclical path is the underlying political dynamics. It has two mutually reinforcing parts: (i) The learning-to-rule part. The experienced colonial powers managed to set Africa on a nice growth path. The inexperienced new governments led the continent into economic trouble. And then they learned. ${ }^{3}$ (ii) The reacting-to-colonialism part. The dynamics of independence caused African politicians to promise far more than they could possibly deliver. Also, they ascribed all problems to the misrule and exploitation of the imperialists. By pursuing different policies they would do much better, but it became a tragedy, and time passed so the urge to differ from the old colonial policies weakened and hence the second shift. This political dynamic corresponds to the three phases in the dominating development strategy in Africa: D1 to D3: ${ }^{4}$

(D1) From 1950 to about 1965 the countries had MS, market systems, as preferred by the main colonial powers. ${ }^{5}$ In several countries independence came later and hereby the possibility to choose another development strategy. (D2) The 20 years 1965/85 was the $A S$-period of African Socialism. A main purpose of these policies was self-reliance. It was to be reached by insulating the economies from the world market. (D3) From about 1985 the preferred economic system changed back to an MS, and to go there a set of $S A$, Structural Adjustment, of trade liberalizations and SOE (state owned enterprises) privatizations were implemented.

This zig-zag movement in economic ideology is typical for the LDC world, though it has been relatively strong in Africa. Thus, African Socialism was the typical ISI-package, for Import Substitution Industrialization, with trade protection and SOEs. At a first glance, the three Ds do not appear to correspond to the three Ps. Section 5 looks at data showing the cycle in the actual policies. Due to implementation lags the correspondence turns out to be much better than it appears at first.

3 It is a problem for this explanation that two of the countries that have followed the cyclical path most closely are Ethiopia and South Africa (not included).

4 It is difficult to classify development strategies in periods, but the two strategies D2 and D3 chosen by the African countries themselves, were also the strategies advocated by the organizations speaking for Africa, such as the Organization for African Unity/African Union and the UN Economic Commission for Africa.

5 Prior to World War II the African countries had economic systems that might be characterized as colonial systems, but fairly soon after the war it became clear that most colonies might be independent at some future point in time, and the main colonial powers started policies to create viable economic systems. 


\subsection{Two Exogenous Shocks: The Oil and the Debt Crises}

In the 60-year period Africa was hit by two strong international shocks. They affected all three country-groups shown in Figure 1, but somewhat differently:

The Oil Crisis of 1973. It originated in the Middle East, and affected most countries from 1974/75. Part of the downswing in P2 was no doubt due to the Oil Crisis, but as shown on Figures 1 and 6 the kink started a bit before in Africa. Also, the downswing due to the Oil Crisis ought to have been relatively modest in Africa for two reasons: (i) The policies of self-reliance pursued. (ii) The African countries have relatively large subsistence sectors, which should not be affected at all. However, the fall in the growth rate was relatively large.

The Debt Crisis of 1982. From 1973 to 1982 most LDCs borrowed heavily to offset the effects of the Oil Crisis, and outside Africa the kink in 1973 was small. However, debt burdens rose ominously. In August 1982 this led to a chain reaction of defaults starting in Latin America. For most LDCs the kink came in 1982 and caused one decade of zero growth - known as the lost decade in Latin America. In Africa the kink came a decade before and had a much weaker connection to debt. It caused the growth tragedy of two decades of negative growth. The effect of debt is further discussed in section 4.6.

\subsection{The African Divergence in P3, and a Summing Up}

Figure 2 shows the relative distribution of incomes - the $\sigma$ measure of convergence - of the 44 countries compared with a similar curve for the West. The two country-groups had a similar relative income difference in 1950, but while the West converged, Africa stayed at the same level till P3, where a strong divergence started. Thus, the average African curve on Figure 1 makes sense till 1992, but it is less representative since then. The upswing since 1993 has affected some countries more than others.

Consequently, this section has shown that the African development is unusual in two ways: (1) It has had a relatively strong cyclical path, and (2) a relatively low average growth rate. The two facts interact: Imagine that the downswing in P2 had been only half of what it actually was, i.e. -1.22 percentage points only. Instead of the $1.16 \%$ growth rate reported, this would have caused Africa's growth to have been $1.60 \%$. It would still have been lower than the one of the two other groups in Table 1, but not much lower. The low growth is thus partly but not fully - due to the growth tragedy of P2. 
Figure 2: Convergence/Divergence in Africa and the West - by the $\sigma$-Measure

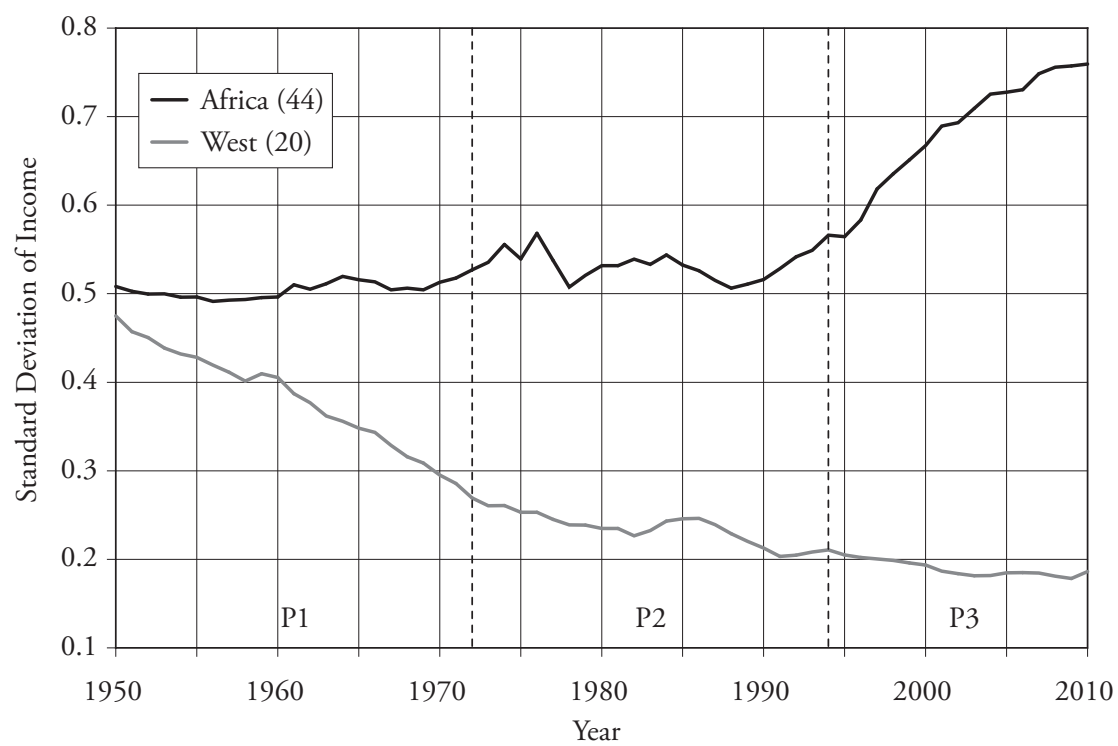

Note: The $\sigma$ measure of convergence is the standard deviation of income, i.e., of the logarithm to GDP per capita.

Data source: MADDIson (2003).

Section 3 looks at the low growth of Africa, while the rest of the paper concentrates on the cyclical path. A convincing explanation of the cycle needs to have two characteristics:

a It has to work through variables that are time variant over the three periods.

b The variables have to be able to affect growth sufficiently to explain the cycle. 


\section{Looking in the Textbooks for General Explanations}

The Maddison data have $(44 \times 58=) 2,552$ African growth rates, of which $35 \%$ are negative. The theory of economic growth suggests that the low growth of Africa is due to a low level equilibrium trap. I cover the two main traps proposed in the literature by asking if the data look as demanded by these theories. The many negative growth rates lead to a third possibility: Maybe a negative shock can put an African economy on a stable negative growth path?

\subsection{Malthus' Low Level Trap}

The first theory of a low level equilibrium trap goes back to Malthus (see BLAUG, 1962, ch.3). The trap is that increased income causes an extra population growth, wiping out the income per capita increase. Figure 3 shows how well income explains the net-population growth rate.

If Malthus' theory explained Africa's development in the last 60 years, the kernel-curve curve should have a positive slope in Figure 3. The kernel is a continuous average with a fixed bandwidth. At the start and end the average is only supported by few observations, but from about 6 to about 8 the curve is well estimated. The positive slope should be most prominent at the left hand side of the graph.

The figure shows no signs of a positive slope. The kernel-curve has an insignificant negative slope for most of its range until the last observation is added. If the bandwidth is reduced, the kernel becomes less stable at the ends, but stays the same in the range with many observations. The explanation of Malthus therefore seems irrelevant. ${ }^{6}$

The level of African population growth is high. Over most of the income range, i.e. from 6 to 8 on the horizontal axis population growth was stable around $2.7 \%$, which is close to the biological maximum of just above $3 \%$. This gives the African countries population increases of 4.5 times $( \pm 0.3)$ in the last 60 years. $^{7}$

6 For 1700 and 1820 data exist for 12 Western countries. The annual gdp and population growth rates were $0.12 \pm 0.05$ and $0.45 \pm 0.11$, respectively, so it made sense that Malthus discussed if the real growth could be wiped out by small changes in population growth. The numbers for Africa since 1950 are quite different.

7 It has often been suggested that Africa could have had the same gross growth with half the population growth. This would have increased the real growth rate per capita from $1.2 \%$ to about $2.5 \%$. See also Boserup (1965). 
Figure 3: Looking for Malthus' Trap: Population Growth over Income

Epanechnikov kernel bandwidth 0.5

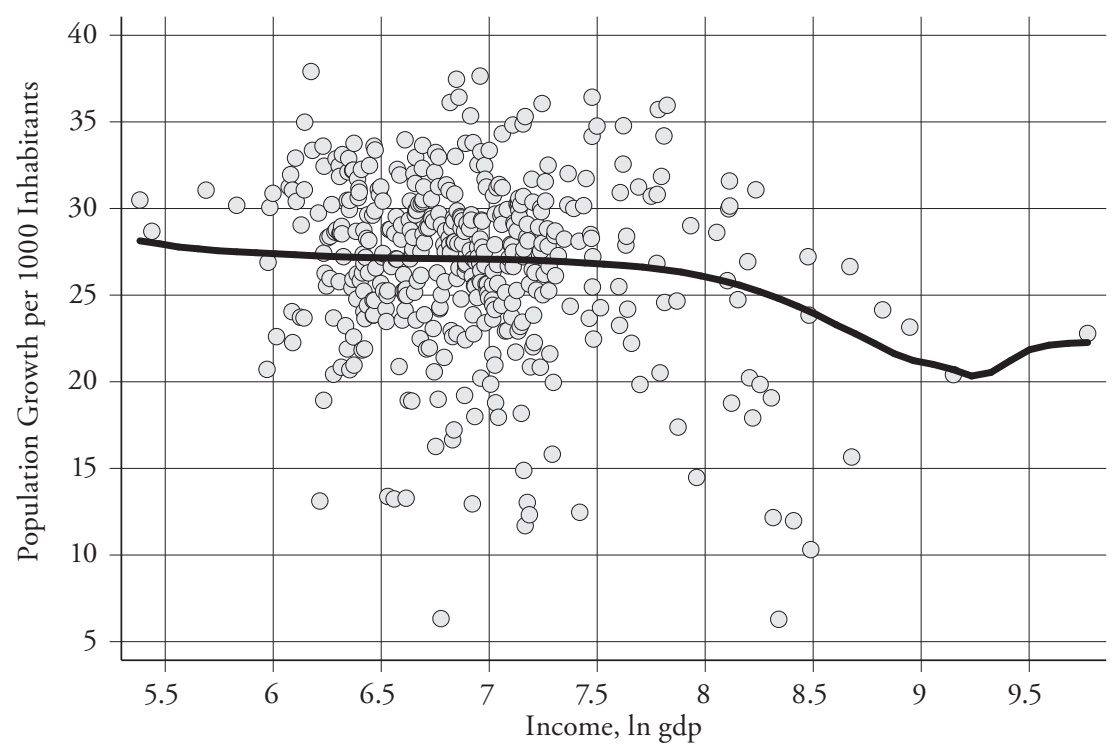

Note: The curves are made for 10 observations per country for income and crude population growth. The income data on the horizontal axis are for the years 1960, 1965, .., 2005, and the vertical axis considers averages for 1960/64, 1965/69, .., 2005/08.

Sources: MADDISON (2003) and WDI.

\subsection{Solow's Low Level Trap}

In standard growth textbooks a version of the Solow model with two equilibriums is quite common. It is drawn as in Figure 4, showing a double-humped production function. The model has two attractors $\left(k_{\text {low }}, y_{\text {low }}\right)$ and $\left(k_{\text {bigh }}, y_{\text {bigh }}\right)$, see Aziariadis and Stachurski (2005).

If $0<k<k_{\text {piv }}, k$ converges to $k_{\text {low }}$, which gives one attractor $\left(k_{\text {low }}, y_{\text {low }}\right)$.

If $k_{\text {piv }}<k, k$ converges to $k_{\text {bigh }}$, which gives another attractor $\left(k_{\text {bigh }}, k_{\text {bigh }}\right)$.

The model thus has the pivotal point $\left(k_{p i v}, y_{p i v}\right)$ that is an unstable equilibrium.

The trap property of the model is that if income rises for some reason, but does not exceed the pivot, it falls back to the low equilibrium. When $y_{\text {low }}$ and $y_{\text {bigh }}$ are 
Figure 4: The Solow Model with a Low Level Equilibrium Trap

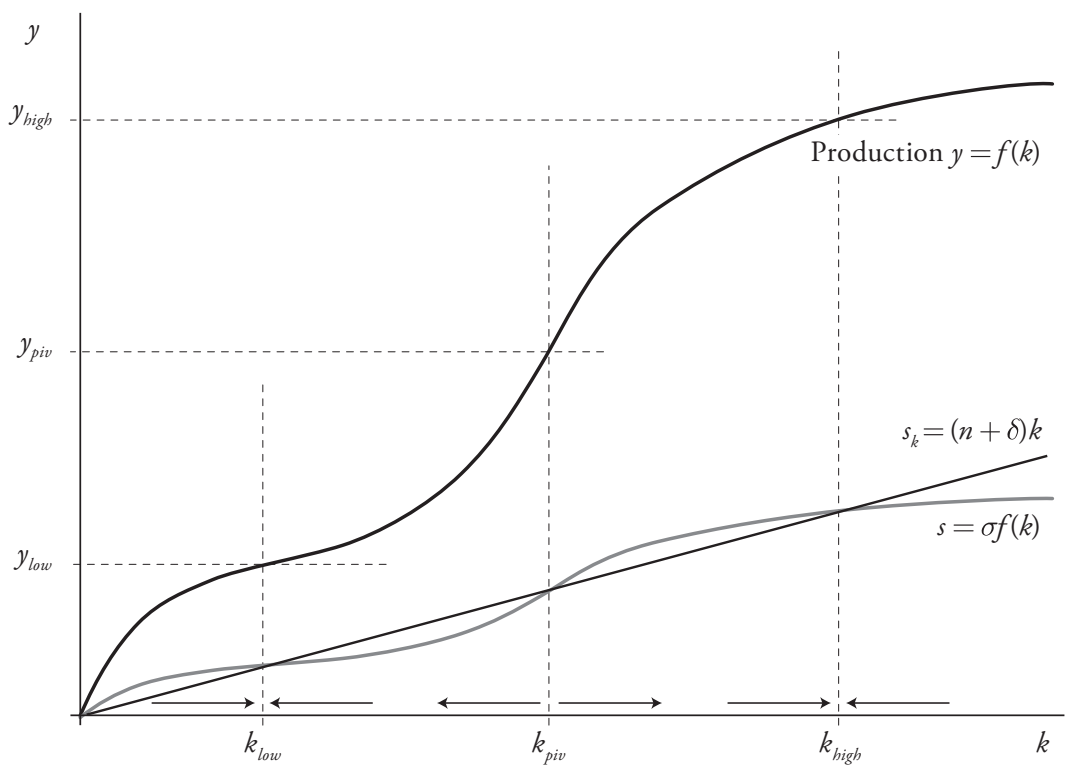

Note: The model contains the production function $y=f(k)$ where production $y$ and $k$ are production and capital per capita, and $f$ has all the necessary 'niceness' properties. The savings-investment function is $s$, where $\sigma$ is the propensity to save. The $s_{k}$-function models the savings that keep $k$ constant, where depreciation $\delta$ and population growth $n$ are covered. For a lucid textbook presentation see Jones (2002).

wide apart, as e.g. the income of the average African and Western country, and $y_{p i v}$ is somewhere in the middle, it becomes difficult for an African country to ever exceed the pivot. Several explanations can be given why the production function may be double humped. The principal being that it aggregates a dual production structure, where the modern production technology has a large barrier to entry in the form of capital requirements.

The $\left(k_{\text {high }}, y_{\text {bigh }}\right)$ equilibrium is well-known. It is a production at the 'world' technology level of the West. It suggests that all DCs (for developed countries) converge to the same steady state precisely as shown in Figure 2. This has been known since BAUMOL (1986).

Imagine that the $\left(k_{\text {low }}, y_{\text {low }}\right)$ equilibrium is, in the same way, determined by a common technology. This appears possible in a continent where all countries have borders to each other and are isolated from the rest of the world by large oceans and wide deserts. Thus, there may be convergence to a common equilibrium. 
Figure 5: Looking for Solow's Trap: Income Growth over Income

Epanechnikov kernel bandwidth 0.5

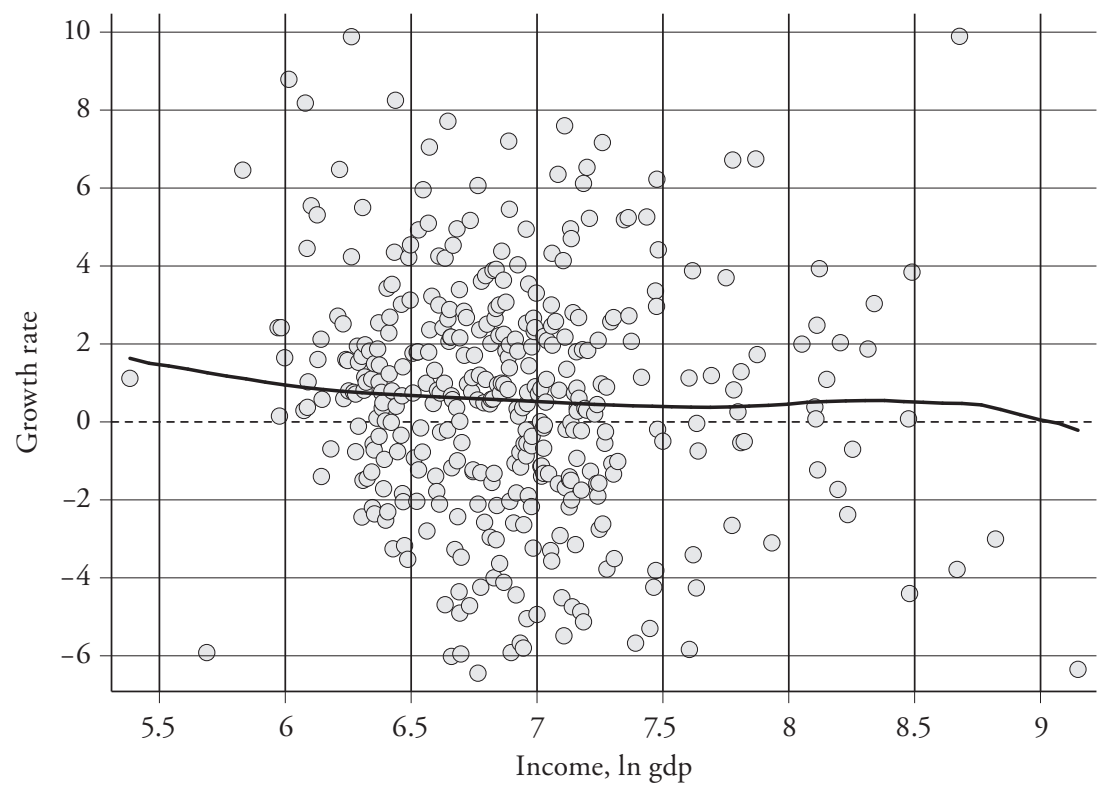

Note: The data are 9 observations per country for initial income (ln gdp) for the years 1960 , $1965, \ldots, 2000$, and the vertical axis considers average growth for 1960/64, 1965/69, .., 2000/04. Thus, $N=396$, but 11 observations are outside the frame.

Data source: MADDISON (2003).

Figure 5 is calculated as Figure 3. If there is a low level equilibrium, a substantial part of the kernel-curve to the left should have a negative slope. The kernel-curve actually has a negative slope, but the slope is modest, and in the standard convergence regressions it is insignificant. ${ }^{8}$ Thus, it does not appear that the African continent has been held back in a low level equilibrium trap.

8 The regression for absolute convergence with $N=396$ is: $g y=+1.71(0.7)-0.13(-0.4) y$ with an $\mathrm{R}^{2}=0.0004$, where $y$ is (initial) income, $g y$ is the growth of gdp and brackets hold $t$-ratios. If the 11 extreme observations are deleted $\mathrm{R}^{2}$ increases to 0.012 , and the coefficient on $y$ decreases to $-0.63(-2.2)$, which is significant, but still small. If the 4 additional extreme observations (two to the left and two to the right) are deleted, the coefficient on income once again vanishes. 
Table 2: The 24 Countries with the Worst Economic Performance 1950-2008

Countries with negative or negligible growth 1950-2008

\begin{tabular}{llccc}
\hline Country & $\begin{array}{c}\text { Growth }^{\text {a) }} \\
\text { since } 1950\end{array}$ & Peak & \multicolumn{2}{c}{ Since peak } \\
Growth
\end{tabular}

Countries with peak well before 2008

\begin{tabular}{|c|c|c|c|c|c|}
\hline & \multirow[t]{2}{*}{ Country } & \multirow{2}{*}{$\begin{array}{c}\text { Growth }^{\text {a) }} \\
\text { since } 1950\end{array}$} & \multirow[t]{2}{*}{ Peak } & \multicolumn{2}{|c|}{ Since peak } \\
\hline & & & & Years & Growth \\
\hline 13 & Senegal & 0.3 & 1965 & 43 & -0.1 \\
\hline 14 & Gabon & 0.4 & 1976 & 32 & -3.6 \\
\hline 15 & Zambia & 0.4 & 1965 & 43 & -0.7 \\
\hline 16 & Burundi & 0.5 & 1991 & 17 & -2.4 \\
\hline 17 & Angola & 0.8 & 1973 & 35 & -0.0 \\
\hline 18 & Kenya & 0.9 & 1990 & 18 & -0.1 \\
\hline 19 & Gambia & 0.9 & 1979 & 29 & -0.5 \\
\hline 20 & Congo, $\mathrm{Br}$ & 1.0 & 1984 & 24 & -1.4 \\
\hline 21 & Cameroon & 1.0 & 1986 & 22 & -1.5 \\
\hline 22 & São Tomé & 1.0 & 1980 & 28 & -1.1 \\
\hline 23 & Rwanda & 1.1 & 1983 & 25 & -0.1 \\
\hline \multirow[t]{2}{*}{24} & Guinea Bissau & 1.3 & 1975 & 33 & -1.2 \\
\hline & Average & 0.8 & 1979 & 29 & -1.1 \\
\hline
\end{tabular}

Note: Several country names are shortened. The first two letters of the capital city distinguish the two Congos.

a Growth is the average annual growth of gdp (real GDP per capita). Source: MADDISON (2003). 


\subsection{A Steady State Negative Growth?}

The third possibility is that the African economies can generate a steady state negative growth rate. Thus maybe a negative shock as the oil crisis of 1973 set the countries on that path. Table 2 shows the worst performers as regards growth.

The table has two sections. The upper panel shows the 12 countries mentioned as one part of the growth tragedy in section 1 . These countries had some growth in the 1950s and 1960s, but they peaked around 1973 and in the last 35 years they have had falling gdp by an annual rate of $1.8 \%$. The lower panel covers an additional 12 countries that had a positive growth over the full 58 years period, but where a peak occurred some time ago and the income has been falling since then. The average peak year is 29 years ago and the fall in income is on average $1.1 \%$ since then.

Thus more than half of the African countries have had 3-4 decades of falling income. I have analyzed the distribution of the 2,552 growth rates. If a stable negative growth rate exists, the distribution should be bimodal, with a second peak in the negative section of the distribution. Growth rates typically have a symmetrical distribution with long tails, and so do African growth rates. I have found no indications of a negative peak in the distribution.

We may also turn to the theory of economic growth and ask: What are the conditions under which the growth rate becomes negative for 3-4 decades? The Solow-model has the production function:?

$$
Y=F(A, K, L, H)
$$

It can only produce negative growth (per capita) under two circumstances:

i Investments are so low that the capital stock is constantly falling and the elasticity of substitution is small. In the limiting case of a Harrod-Domar model it might happen, if savings are small. But the average African country receives about $14 \frac{1}{2} \%$ of GDP in development aid, which in principle is meant to finance development. ${ }^{10}$

$9 \quad Y$ is GDP; $A$ is technology; $K$ is the real capital stock; $L$ is the labor force; and $H$ is the stock of human capital.

10 If $8 \%$ of the $141 / 2 \%$ aid finances investments and there are some additional investments, the share of investments (in GDP) in Africa is well above $10 \%$. This means that $K$ must be growing. This assumes full fungibility; with less than full fungibility the investment share is higher. 
ii Technical progress is negative, which means that techniques are forgotten at a steady rate. This also appears fanciful. Human capital has actually increased in Africa at a rather satisfactory rate, and under these conditions $A$ is unlikely to fall.

Thus, it is not easy to explain the long periods of negative growth in many African countries. However, model (1) may be expanded. I propose that $E s$, the economic system of the country, is added:

$$
Y=F(A, K, L, H, E s)
$$

In the last 60 years two groups of poorer countries have had savings/investment rates of twice the ones of the West: East Asian and East European. While the former are the East Asian high growth countries that did catch up with the West, the latter were Communist countries where the gap to the West widened. Obviously, an inefficient economic system can hinder large investments in generating much growth. Maybe the negative growth in period P2 in Africa was due to a combination of small to moderate investments and a change into a bad economic system as discussed in section 5 .

\section{Specific Factors Explaining Africa's Development}

As the general explanations seem irrelevant, researchers have looked for specific explanations. This section first considers five theories proposed in the literature on P2, the African growth tragedy, and then two theories that are supposed to be more broadly applicable. Each of the seven theories claims that one factor is crucial for the poor growth performance. ${ }^{11}$

To a large extent the specific explanations are a reaction to the theory that the cyclical path of Africa can be explained by the underlying political dynamics as set out in section 2.2. This explanation appeared too easy, and this has generated a body of literature trying to explain the African growth tragedy by more exogenous factors. The five leading ones are:

(1) Bad geography: (a) many landlocked countries, (b) widespread diseases, (c) uncertain rainfall and poor soils.

11 Some of the factors may overlap, and several of the factors may work independently at the same time. 
(2) Bad history: (a) the slave trade, (b) imperialism and (c) the colonial legacy.

(3) The tribal structure of the African countries/the arbitrary borders of the countries.

(4) The relative high frequency of war/civil war.

(5) Poor governance.

\subsection{Bad Geography}

The key modern paper on the poor geography of Africa is GALLUP, SACHS and MeLLinger (1999), which builds on several predecessors notably Gourou (1966) and KamarCK (1967). Geography is basically time invariant, but the importance of a geographical factor may change with technological progress. ${ }^{12}$

The factor of poor location may change with better transport technologies, the fertility of soils may increase with new agricultural technologies, and the high frequency of some diseases in Africa may fall with medical progress and when development changes the organization of society. ${ }^{13}$ In poor countries geography is thus more important than in wealthy. However, technical progress gives trends, not cycles, in the importance of the factors.

\subsection{Bad History}

It has sometimes been argued that the pre-colonial history dominates development today. NunN (2008) argues that effects of the slave trade are important till this day. The trade was concentrated in the $18^{\text {th }}$ century (see CurTin, 1969), so it appears a bit far-fetched, and it can certainly not explain the cycle of African development $1 \frac{1}{2}$ century later. Also, the areas most affected by the trade appear to be precisely the most developed ones, due to their good location relative to international trade.

The main historical explanation is the imperialism family of ideas, which were popular in the 1960s and 1970s, see e.g. FANON (1961) and Rodney (1972). These theories claim that it explains African poverty that most of Africa was

12 Apart from microstates Western Europe has only two landlocked countries (Austria and Switzerland). That they are landlocked is no problem today but perhaps it was 200 years ago.

13 A relevant story is the one of malaria, which is particularly widespread in Africa for geographic reasons. Today it is controllable with enough organization, but the creation of such organization is conditional on development, so malaria has a complex causal relation to development, see Carstensen and Gundlach (2006) for a survey of the discussion and the empirics. 
under imperial exploitation. However, it does not explain future growth, but rather predicts that growth should explode after independence. Also, of course, the longer lasting colonies have good geography and a better development than the colonies of shorter duration. So causality is difficult to untangle, and if colonial past is a problem, the effect should be falling over time and not have a cyclical path.

The problem for these explanations is that most countries have been colonies in various periods of their development, and the data rather point to colonial past as an advantage; see LA PORTA et al. (1998) and GrIER (1999). These studies, and a handful of later ones, discuss if the different colonial legacies influence future growth. Figure 6 divides the 44 countries into three groups: 14 exBritish colonies, 17 ex-French colonies and 13 others (ex-Portuguese, ex-South African, ex-Spanish and independent). The paths for each group are strikingly similar. The colonial legacy of countries is not the decisive factor for the cycle in their development.

Figure 6 has an additional implication. Below, a handful of institutional indices are considered. They are rarely complete for all 44 countries and the full period from 1950 to 2008. Figure 6 suggests that even if the data have gaps, the main trends are so strong that they also appear in random samples of the countries.

\subsection{The Tribal Structure}

Tribal diversity is an important fact of life in Africa, and EAsterly and Levine (1997) claimed that it is the key to the growth tragedy. The ethno-linguistic fractionalization index is calculated from a classification of the ethno-linguistic groups of each country. ${ }^{14}$ The index shows the probability that two arbitrarily chosen people from a country belong to different groups.

Table 3 shows that the average African country is relatively divided. One of the most divided countries in Europe is Switzerland where the index is 0.58 . The average African country is even more divided. The literature since EASTERLY and Levine (1997) has developed a handful of related indices from the underlying data. They might be related to the underlying long-run growth, but the tribal structure changes slowly and cannot explain the cyclical pattern of African development. The tribal structure partly created by the arbitrary borders may be the factor behind the next two explanations.

14 The indices should be almost time-invariant, but several classifications of tribes and religions are possible and the available information differs over time - and so do the indices (see RoEDER, 2001). Also, the indices may reflect religious differences as well. 
Figure 6: A Division of the 44 African Countries by Colonial Legacy

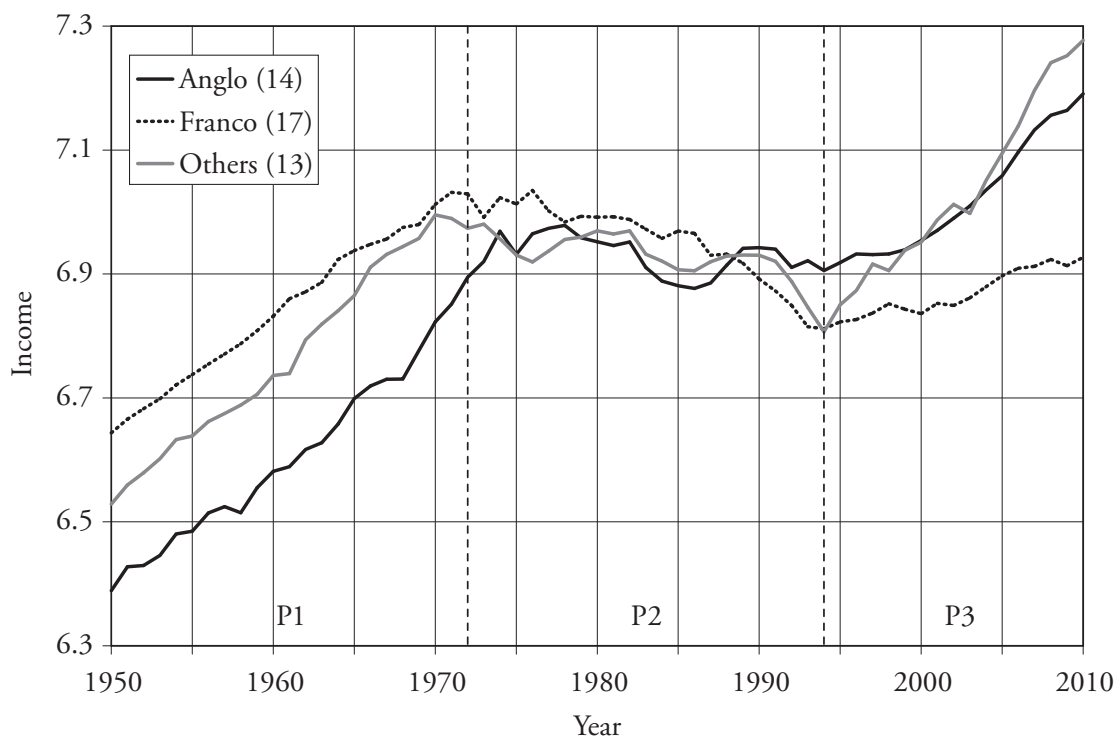

Data source: MadDison (2003).

Table 3: Average Values of the Ethno-Linguistic Fractionalization Index

\begin{tabular}{lllc}
\hline & Avr & Std & N \\
\hline Africa & 0.66 & 0.23 & 45 \\
West & 0.28 & 0.21 & 25 \\
Others & 0.41 & 0.25 & 100 \\
\hline All & 0.46 & 0.27 & 170 \\
\hline
\end{tabular}

Note: The values from the ELF85 index.

Source: Roeder (2001).

\subsection{Many Wars/Civil Wars}

A great deal of effort has been put into documenting the extent of war/civil war in the world. The various indices point to Africa as the most war-plagued continent. This certainly has costs in the form of a growth loss. Figure 7 shows the path of conflicts from the PRIO (references). Till 2000 there is a clear upward 
trend in the two series. Thus, the data supported the analysis of Collier and Hoeffler (2004), up to a point. In P1 the various uprisings against the colonial power ceased and things looked well, but then pre-colonial conflicts resumed and new conflicts started, mostly due to tribal tensions. P2 starts with a dip in conflicts, but then they rise steadily. P3 starts with a small dip, but then the level rises - however, after 2000 conflicts fall. Thus, the path of conflicts does not follow the cyclical development in Africa.

Figure 7 rather looks as if causality is from development to conflicts. Period 1 contains the big liberation wave where countries move out of imperial peace and can fight without interference. In period P2 there is a significant upward trend so negative growth leads to more war. In period P3 the trend is down so that new growth leads to less war.

Figure 7: The Paths of the PRIO-Conflict Indices for Africa

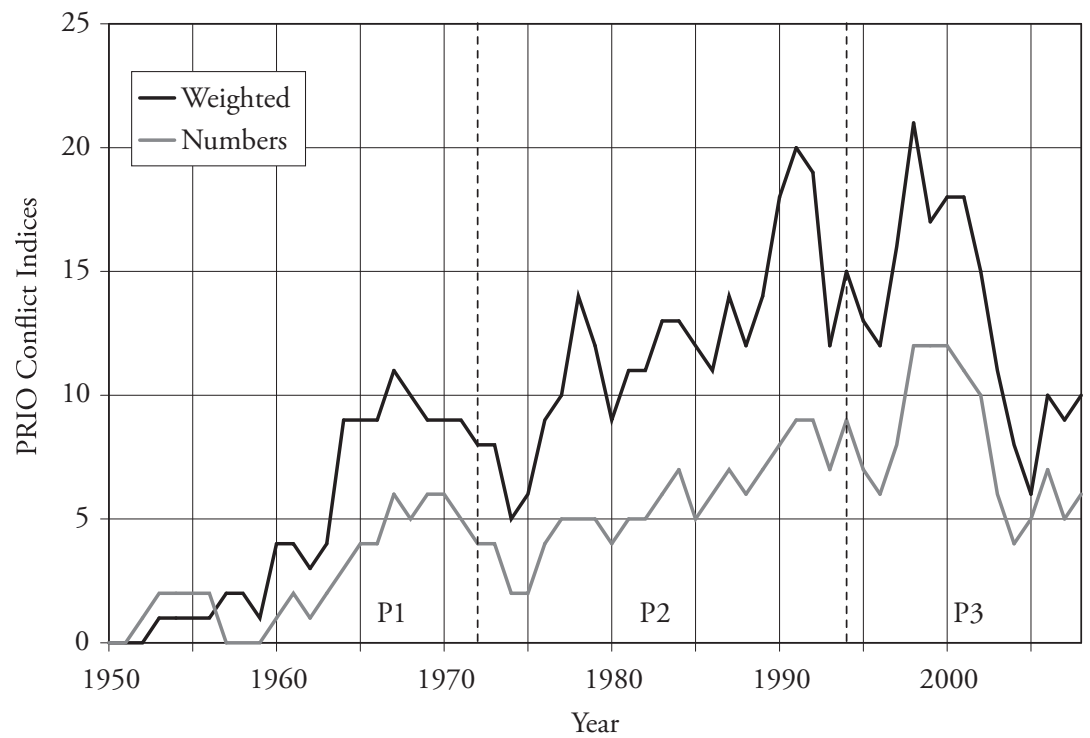

Note: Weighted has two values 1 if more than 25 are killed, and 2 if more than 1000 are killed. Number counts the number of conflicts where more than 1000 have been killed since the conflict started. I have only included the largest conflict in each country. 


\subsection{Poor Governance}

It is easy to tell stories as do HARDEN (1991) and with acerbic wit NAIPAUL (1976) about bad governance in various African countries, but the world has seen many bad governments, also on other continents. The data do not confirm that African governments are unusually bad. Both the two main democracy indices (Polity and Gastil) and the Transparency International corruption index get an insignificant coefficient to Africa when controlled for income. ${ }^{15}$

The PTS-index (references) gives Amnesty International's evaluation (19762009) of the level of government terror directed at the population. The index is scaled from 1 to 5 , where 1 is the ideal and 5 is for terror that covers everybody. The West is $1.58 \pm 0.02$, Africa is $2.91 \pm 0.03$, and all other countries are $2.90 \pm 0.02$, so if corrected for income, African countries are less brutally ruled than other countries. When these data are considered in more detail, some country-scores appear surprisingly unfair, but the calculations are done on all 4,485 available observations so they are robust to a great deal of measurement error.

Figure 8 compares the paths of the PTS-index for state terror and the Polity II index (references) rescaled to the PTS-scale. Polity is thus 1 for a fully authoritarian regime and 5 for full democracy. The graph shows that the level of democracy increases with a full Polity-point just after 1990 and has even increased by another half point since then. However, at the same time the PTS-index went up, indicating an increase of suppression with half a point. Section 5 argues that the two seemingly contradictory developments may both be true.

From the analysis of governance it is clear that Africa suffers from bad governance, but only to the extent corresponding to the poverty of the continent. Poor countries have a low level of executive capacity.

\subsection{Hypotheses Related to all Three Periods: \\ Debt and Commodity Price Movements}

Several additional explanations have been applied to both the shift from P1 to P2 and the shift from P2 to P3. ${ }^{16}$ Two will be discussed:

As mentioned in section 2.2 the African countries have seen a large debt cycle in the period from 1970 and onwards (see Freytag and PALDAM, 2011). The big

15 See Gundlach and Paldam (2009) for the Polity democracy index; Paldam and Gundlach (2011) for the Gastil democracy index (from Freedom House); and Paldam (2002) for the corruption index.

16 The literature on P3 is modest at present, see Arbache and Page (2010), Johnson, Ostry and Subramanian (2007) and Beny and Cook (2009). 
Figure 8: The Path of Governance

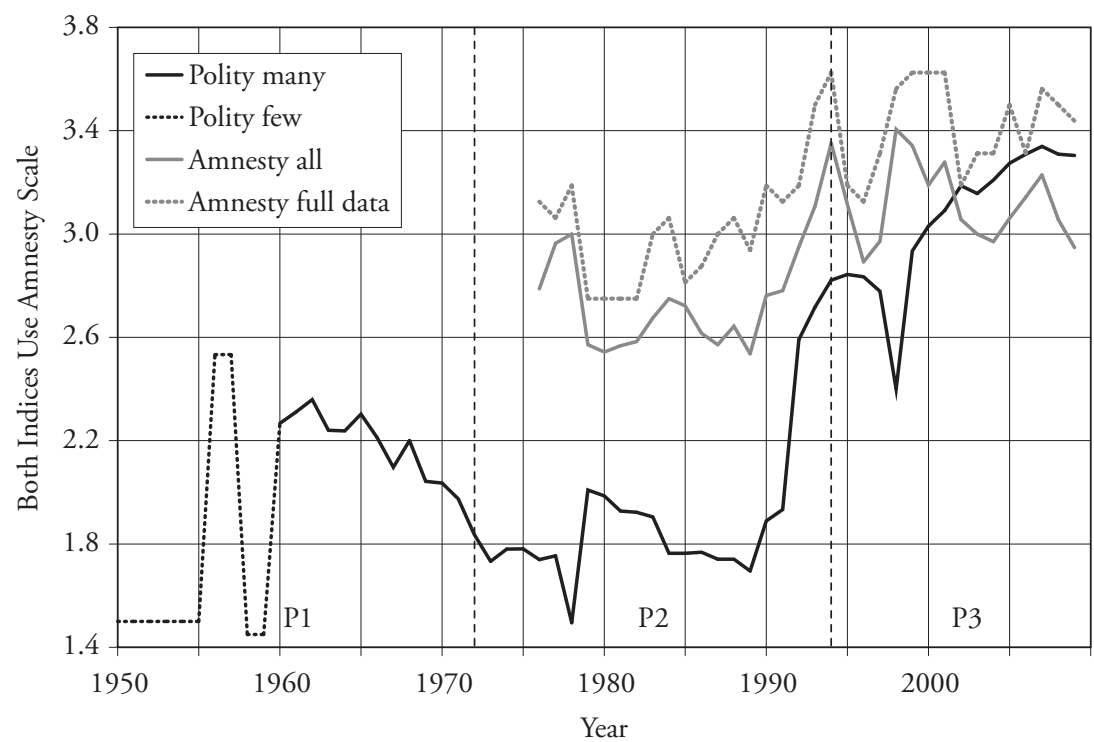

Note: Amnesty 1 is the PTS index for all available observations while Amnesty 2 is the average for the countries that have almost complete series (except for a few interpolations). The (rescaled) Polity index covers very few countries before 1960 .

Sources: PTS and Polity home pages.

upswing in debt was clearly a reaction to the crisis so it was not causal for the shift from P1 and P2. Also, the big wave of debt forgiveness was in the period from $2003-05$ so it is not related to the shift from P2 to P3. While the relation between borrowing and growth is negative, it does not explain the cycle of African development. In fact, debt explains little of the variation in growth rates. It is as if the African governments quickly understood that they would never have to pay back what they borrowed.

It is a tradition in Africa - supported by UNCTAD (references) - to ascribe all major internal economic fluctuations to the world market. UNCTAD has compiled the commodity price index shown in Figure 9 to support its argument. The downswing in the growth rate from P1 to P2 was surely triggered by the first oil price shock in 1973 as already discussed. ${ }^{17}$

17 The UNCTAD-data do not cover the commodity price shock in 1951 in connection with the Korea war. It was as large as the Oil shock, but lasted only about one year. This commodity shock did not seem to have had much effect on African development. 
The next major change in the development path of the African countries from P2 to P3 was not triggered by commodity price shocks. Several papers, notably BENY and COOK (2009), discuss if the world market had some role to play. They do find some small effect, but if the last decades of period P2 and P3 are compared, there do not seem to be important systematic changes in commodity prices that can explain the shift.

Figure 9: UNCTADs Commodity Price Index

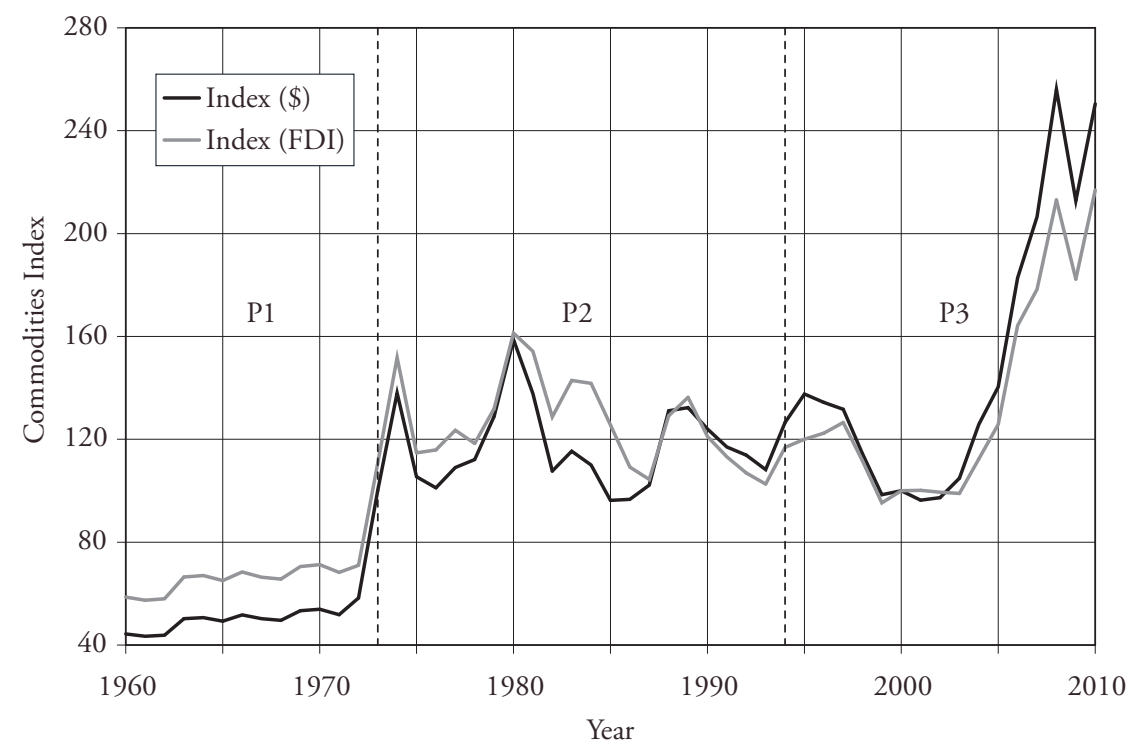

Note: The two versions show commodity prices relative to the US\$ and the FDI.

Source: UNCTAD.

It is interesting to see that the commodity price shock around 2005 is larger than the one in 1973, but the effects on the growth rates (see Figures 1 and 6) are barely noticeable. 


\section{The Cycle of Development Strategy}

The underlying political dynamics of section 2.2 suggest two major shifts in development strategy: (D1) The colonial powers had installed an MS, Market System, when the countries became independent. (D2) From about 1965, the African countries started to pursue AS, African Socialism. (D3) From the mid 1980s they turned to a policy of SA, Structural Adjustment, returning the countries to an MS. As suggested by the abbreviations, the AS and SA policies are the reverse. AS is a policy of regulation and SA is a policy of deregulation.

\subsection{The Path of Economic Regulation}

The best data available for the degree of regulation in African are the Fraser Index of economic freedom, which is defined as the freedom to run a private business. This is an index of policy outcomes, so it differs from the economic ideology by the implementation lag.

The index measures the distance to the laissez faire, ${ }^{18}$ on a scale where 10 is this ideal, and 0 is as far into regulation as a country can possible get, or a collapse of law and order. The data started in 1970 where only 5 African countries were covered. Later the African sample increased to 33 countries. The average of all observations for Africa is $5.48 \pm 0.9$, so the level is moderate. The West has $7.15 \pm 0.9$ and others have $6.30 \pm 0.6$.

Figure 10 shows the path over time for these data. The black line covers the 5 countries with almost full data (with only one interpolation), while the gray line is an estimate of the path for all of Africa. It is constructed as explained in the note. It is not very precise, and it only starts in 1970. It appears likely that the level in the colonial period before 1960 was about $6 .{ }^{19}$ So the data show a cyclical path. It corresponds to the three periods:

P1 1950-72: I assume that the index was 6 between 1950 and 1960. Gradually after 1965 , the AS was introduced. It increased the level of regulation to just below 5 in Africa. The increase tapered off after 1975, but it only peaked around 1985.

18 The laissez faire has law and order and no more regulation. The closest to this ideal is Hong Kong, where the index is around 9, while the lowest value recorded is 2.3 for Nicaragua in 1985. The few recorded values from Eastern Europe in the Communist period were in the range from 3 to 5 .

19 At that time the colonial powers probably had index values a bit below 7, and the legal systems in Africa were less efficient than in the colonial 'motherlands'. 
Figure 10: The Fraser Index for Economic Freedom

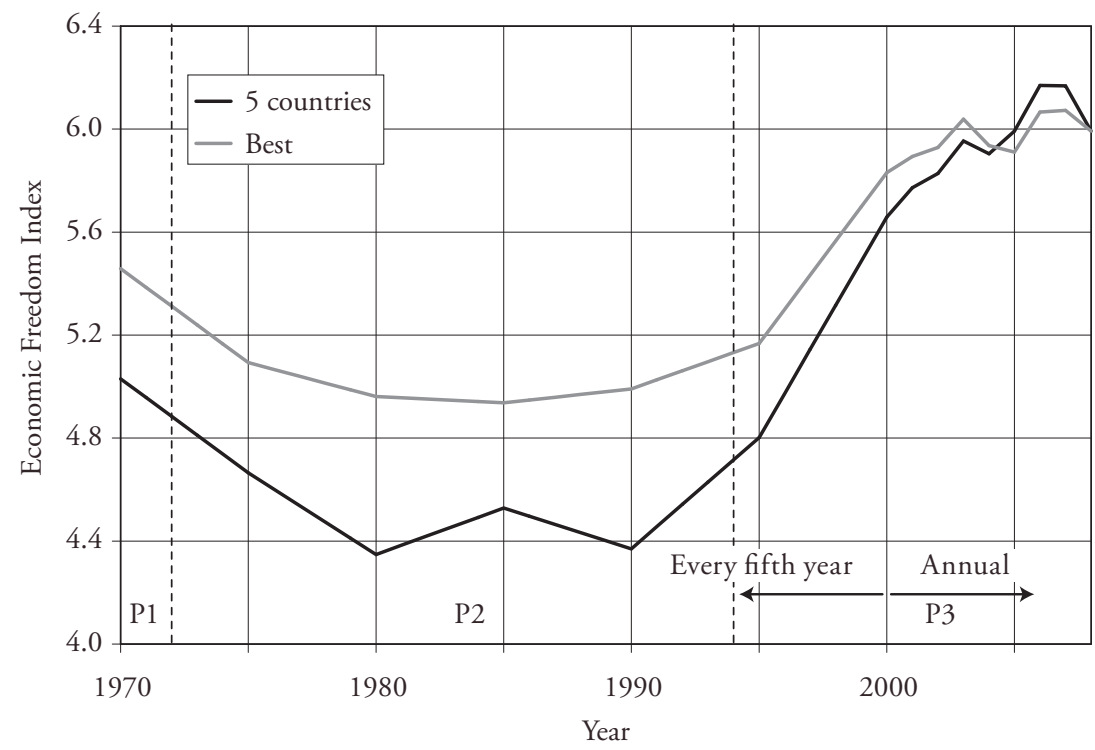

Note: The index covers 33 countries. Only 5 of these are covered all years. The 'best' line is calculated by starting in 2008 where all 33 countries are covered. The observation for 2007 is the average for 2008 minus the average change from 2007 to 2008 for as many countries as possible. The observation for 2006 is the average for 2007 minus the average change from 2006 to 2007 for as many countries as possible, and so on till 1970.

Source: Economic Freedom Index

P2 1973-93 was the period of the implemented AS-policy regime. One of the main purposes of the AS was to isolate the African economies from the vicissitudes of the world market. Therefore, the countries should have been relatively well-protected when they were hit by the oil crisis, but as already mentioned they were hit harder than everybody else.

P3 after 1993: Here, regulations were released and the economy quickly resumed growth as predicted by the analysis of DE HAAN and STURM (2000).

Of all indicators considered in this paper, none corresponds so well to the three phases in the development of Africa as the Fraser Index. It 'explains' both the shift from P1 to P2 and the shift from P2 to P3.

It is arguable that the cycle is optimal according to the infant industry argument. Several schools of thought claim that the import substitution strategy such 
as the ones of the AS-package is the ladder to development, for a new version of the argument see CHANG (2003). ${ }^{20}$ In P2 infant industries were created in a protected environment. When they had grown strong enough, protection was gradually lifted and now the countries have a competitive new industry, and grow faster than before the policy started in P1. The main problem with this theory is that Africa grew before the AS-period and it did not grow faster after the AS period than before. There is no point in going through a period of negative growth if there is no premium at the end.

Hence, I conclude that the explanation for the cyclical development path of Africa is simple: The shift to negative growth was caused by the introduction of the $A S$-strategy, and when it was abolished, growth resumed. It is surely debatable how strong the evidence is, but from now it is taken for granted that the said relation is clear. Also it follows the underlying political dynamics from section 2.2.

\subsection{The Shift from Colonial Mixed Economy to the AS Regime}

The shift from the colonial mixed systems to AS was justified by three beliefs: (1) Industrialization is the key to development. (2) The main generator of economic variability is the world market. (3) The African countries did not generate enough private savings. Thus the AS-package of policies levied substantial taxes on agriculture, see BAtes (1981) and Krueger (1992) and formed many SOEs (State Owned Enterprises) in the industrial sector which were allowed substantial rents by a set of tariffs protecting the economy against the world market.

The shift to SA-policies was also affected by the politics of national independence and the Cold War. Independence was supported by left wingers in the West and by the East Block. So in order to balance between West and East and become more independent, African countries wanted to become more socialist. ${ }^{21}$ However, to be workable the AS-policies must be implemented under two conditions:

20 In the 1960s and 1970s many ISI (import substitution industrialization) schools existed. Also, radical proposals for countries to become self reliant were quite common, see e.g. Amin (1971). The school of African Socialism was typical for these families of thoughts. It is strange that these proposals did not consider the failure of the first major experiment with AS in Ghana under Nkrumah (1958-1966). It was the subject of several detailed studies such as JonEs (1976) and KilLick (1978). Somehow nobody took notice of the economic lesson, yet many noted the great political success of the flamboyant Nkrumah and the rhetoric he used to obtain the success.

21 Independence was also supported by the USA, and the USSR was the last big colonial power, but somehow these facts were often overlooked. 
i Enough market size. Modern firms supply goods for a considerable market. Figure 11 reports one measure of the size of the African economies in 1970 when the countries were well into the building of the AS-system. It shows that at that time 29 of the economies were below $5 \%$ of the Swiss economy in size. This corresponds to the canton of Lucerne. ${ }^{22}$ It is difficult to believe that autarchic development of such a small market is a rational development strategy.

ii Enough executive capacity. The successful development of SOEs obviously put great strains on the efficiency and honesty of the public management of the firms and on the political climate in which the companies operate. ${ }^{23}$

The dynamics of the AS-package were not to create efficient modern industry, but as documented in the multi volume study of BHAGwati and KrUeger (1973-78) and by IBRD (1995) the outcome was to create a dynamic path into inefficiency and political alliances upholding such inefficiency. That is the path was into the rent seeking society.

\subsection{The Rent Seeking Society}

Consider the dynamics of an SOE in a country with a weak administration, no critical press and a substantial level of corruption. The manager is an ex-bureaucrat appointed by the minister after due consultation with the president, who are the de facto owners. Irrespective of the charter of the company, the manager knows that he has to serve the owners, who can give his firm so much protection that it runs with a surplus. As the owners are politicians they have political agendas. The political agendas are typically to generate rents to finance the political support for the owner by employing his clients, i.e. his kin, his voters and his tribe.

So the typical dynamic of the SOEs is an upward slide into excess employment and consequently an upward slide in the level of protection. So instead of getting more ready to face international competition - as predicted by the infant industry argument - the typical African SOE grew less and less efficient and

22 The reader may contemplate the development of the canton of Lucerne as an independent country, which had decided to create high tax barriers and use the tariffs to build a set of SOEs to supply the domestic market.

23 It has been claimed that the policies of the Asian Tigers were the same as everybody else's, but worked much better as their bureaucracies were more efficient, see e.g. RoDRIK (2005). This was not claimed in the 1950s and 1960s, and their policies were actually different, see PALDAM (2003). 
Figure 11: The Size of 44 African Economies Relative to the Swiss Economy in 1970

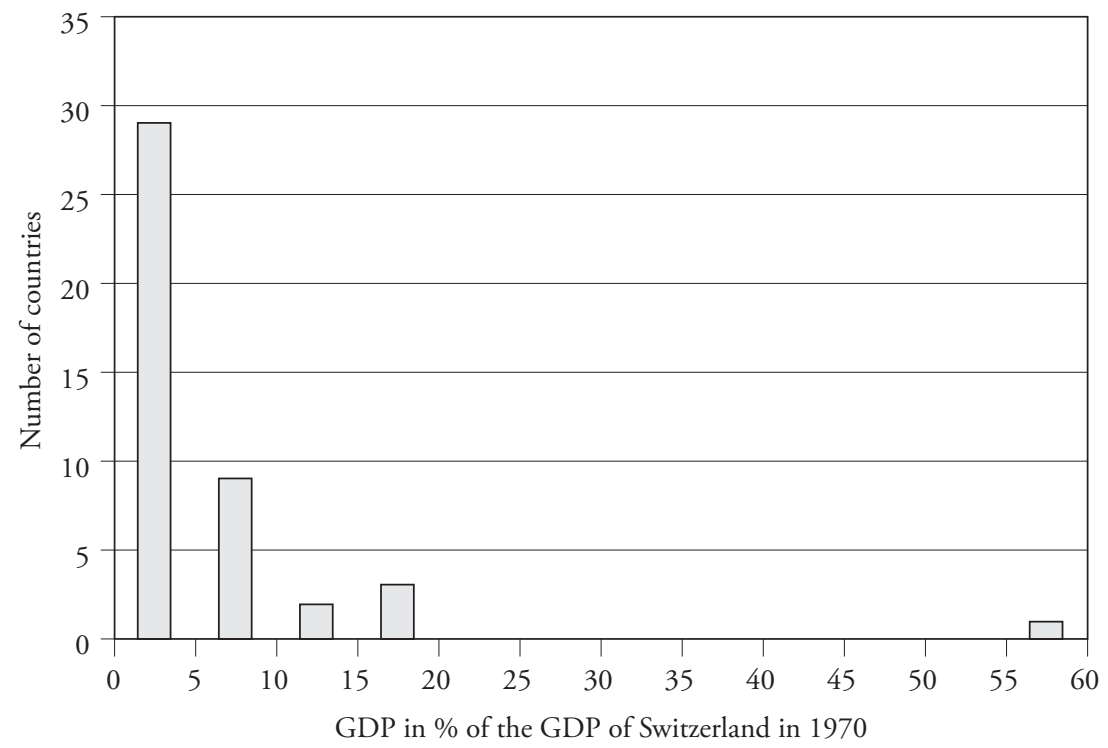

Note: $2 / 3$ of the observations are in the $0-5 \%$ bracket, and only one economy (Nigeria) is above $50 \%$ of the Swiss economy. The same graph for 2008 is similar. Income has grown less than the Swiss income, but population growth is much higher.

Source: Maddison (2003).

more and more politicized. This dynamic seems to give an adequate explanation of the gradual strangling for the African growth in the late 1960s and the negative growth in P2.

The oil crisis was a large price shock on the world market, and it generated an excessively large downturn in Africa. I conclude: (i) The policies had the reverse effect of the one desired, and (ii) the main reason for the size of the downswing was structural. The oil crisis was a trigger for a crisis that would have occurred anyhow. African countries had installed an economic system that made them unusually inflexible, when they were hit by the oil crisis. ${ }^{24}$ My theory is, once again, simple: A rent seeking society is inflexible.

24 KILLICK (1995) is a conference volume that discusses that theory. It asks why most LDCs adjusted better to the oil price shock than the African countries. It is, e.g., shocking to compare the reaction of the two main copper exporters Zambia and Chile to the dramatic fall in copper prices after the end of the Vietnam War. 


\subsection{Adjusting to the New World Order after 1990}

The second big strategy change was influenced by the three factors:

i The AS-policies, which looked promising when they started, had clearly failed.

ii Africa had to adjust after the collapse of world socialism and the end of the Cold War.

iii The Washington Sisters (IMF and IBRD) developed SA-support packages after 1985.

The graphs of Figure 10 show that the change from 1985 to 1990 was marginal only, but after 1990 the change became noticeable. Annual data for the period do not exist, but it is likely that the liberalizations correspond to the upswing of P3 from 1993 till now.

The shifts from P1 to P2 and from P2 to P3 are both about 1 point on the Fraser index - this is a substantial change. The transition from communism in Eastern Europe amounts to about 2.5 points in the index over about 10 years. The transition from African socialism is smaller, but African socialism was more moderate than the Russian brand of socialism.

Not surprisingly it was faster to make changes in the political system - after all African countries had democratic systems de jure - so it was just a question of putting a little more content into the existing institutions, such as allowing opposition parties to run for office, and to stop having critical journalists beaten, etc.

To liberalize the economy, overstaffed SOEs must be turned into efficient companies that are viable on market conditions so that they can be sold. This policy inevitably has considerable social costs in the short to medium term. Even when the SA-loans from the Washington Sisters contained social compensations, it was not always enough. Therefore, it demands some increase in social control, and some repression may result. This might explain the seemingly contradictory trends in Figure 8. However, it is amazing to see that, as the SA-policies were implemented, growth resumed.

\subsection{The Politics of Policy Change}

In many ways Africa is an extreme continent as the data have shown. But this does not mean that Africans are politically extreme.

The World Values Survey has an item asking people about their preferences for private vs public ownership. It has been polled 200 times in altogether 92 countries. Unfortunately only 10 of these polls are made in Africa. BృøRNSKOv and 
PAldam (2011) use these data to calculate a CS-score that measures the preferences for Capitalism/Socialism for each poll. The theoretical range is +100 for full support for capitalism to -100 for full support for socialism, but the observed range is only from +52 to -36 . The average score for Africa is $+1.3 \pm 10.2$, Others are 3.5 \pm 3.3 , and the West is $+26.9 \pm 3.5$. Thus, the African populations are by no means extreme. ${ }^{25}$ Maybe this explains why African Socialism was fairly moderate in most countries. Consequently, deregulation has also been moderate.

The changes shown in Figure 10 are smaller than one should expect from the debates that have accompanied the changes. The discussion of the costs and benefits of SAs has been mixed up in the discussion of neo-liberalism of the Chicago brand. The path depicted in Figure 10, and more anecdotal evidence, shows that the actual changes are in no way a movement between extremes. But policy changes often take place in a dense ideological haze, and seen from afar only the haze may be visible. ${ }^{26}$

While most African countries have been moderate on a socialism/capitalism scale, a few countries have had periods of extreme socialist policies. It appears that these periods were rather destructive. The Fraser index does not point to countries that have pursued extreme libertarian policies so it is not known if growth would have been faster if the SA-policies had gone further.

\section{Conclusion}

The economic development of 44 countries is surely complex. This paper is written on the assumption that the more the development is aggregated, the clearer the basic pattern stands out. And, in fact, a rather clear pattern does appear.

Economic development in Africa has had a cyclical path with three distinct phases: P1 from 1950 (where data start) till 1972 was a period of satisfactory growth; P2 from 1973 to 1993 had negative growth; and P3 from 1994 onwards where satisfactory growth has resumed. The growth in P1 and P3 suggests that the underlying growth rate in Africa is about $2 \%$.

25 The CS-score rises with income, so corrected for income the African populations are rather capitalist minded. Note that the only reason that the two times the standard error is so large for Africa is the small number of observations. The standard deviations are much more similar.

26 The confusion has spread to the moderate common sense rules of thumb known as the Washington Consensus (see Williamson, 1997). They have somehow been politicized so that many think that they are a recipe for libertarian policies (see e.g. STIGLITZ, 2002). 
The cyclical path has been confronted with a set of 11 explanations of the development in Africa, where most are described by one variable. It is likely that some of these variables explain why the underlying long-run growth in Africa is $2 \%$ and not, e.g., $4 \%$. However, most of these indicators have a path that differs from the cycle of African development. Only one fits the cycle:

The development corresponds amazingly well to the changes in economic development strategy. ${ }^{27}$ The African version of the ISI-policy was African Socialism that became the dominant strategy from about 1965 onwards. By the time the package was closest to implementation in the early 1970s, growth turned negative. The downturn was kick-started by the oil-crisis, but then it continued for 20 years.

In the mid 1980s the countries entered a process of deregulation - notably privatizations and foreign trade liberalization - known as structural adjustment. The process started slowly, but by 1995 it was clearly visible in the regulation index, and the process continued till 2000. This corresponds to the upswing in P3, the last phase of the cyclical path.

My interpretation is that this shows that moderate middle-of the road policies serve well also in Africa. The analysis suggests that Africa could have grown with about $2 \%$ per year throughout the period. A growth rate of $2 \%$ is too little to catch up, but it is better than the growth achieved. The AS-policies aimed at a higher growth rate, but failed with tragic consequences.

With the zig-zag in the economic system, Africa still had a doubling of GDP per capita in the period from 1950 to 2008 . The results presented suggest that if Africa had been economically moderate throughout, GDP per capita would have tripled.

\section{References}

Aghion, P., and S. N. Durlauf (eds) (2005), Handbook of Economic Growth, Vol. 1A, North-Holland, Amsterdam.

Amin, S. (1971), "Neo-Colonialism in West Africa", from French edition 1973, Penguin, London.

Arbache, J.S., and J. Page (2010), "How Fragile Is Africa's Recent Growth?", Journal of African Economies, 19, pp. 1-24.

27 The changes are in accordance with the underlying political dynamics from section 2.2. 
Aziariadis, C., and J. Stachurski (2005), "Poverty Traps", in Handbook of Economic Growth, Vol. 1A, P. Aghion and S. N. Durlauf (eds) (2005), pp. 295-384.

Bates, R. H. (1981), Markets and States in Tropical Africa: The Political Basis of Agricultural Policies, several later editions, University of California Press, Berkeley, CA.

Baumol, W. J. (1986), "Productivity Growth, Convergence, and Welfare: What the Long-Run Data Show", American Economic Review, 76, pp. 1072-1085.

Beny, L. N., and L. D. Cook (2009), "Metals or Management? Explaining Africa’s Recent Economic Growth Performance”, American Economic Review, 99, pp. 268-274.

Bhagwati, J., and A. O. Krueger (1973-1978), The NBER Special Conference Series on Foreign Trade Regimes and Economic Development, Ballinger, Cambridge, MA.

Bjørnskov, C., and M. Paldam (2011), "The Spirits of Capitalism and Socialism. A Cross-Country Study of Ideology", Public Choice, doi: 10.1007/s11127010-9711-9

Blaug, M. (1962), Economic Theory in Retrospect, several later editions, Heinemann, London.

Boserup, E. (1965), The Conditions of Agricultural Growth: The Economics of Agrarian Change Under Population Pressure, Allan \& Unwin, London.

Carstensen, K., and E. Gundlach (2006), "The Primacy of Institutions Reconsidered: Direct Income Effects of Malaria Prevalence”, World Bank Economic Review 20, 309-39.

Chang, H.-J. (2003), Kicking Away the Ladder: How the Economic and Intellectual Histories of Capitalism Have Been Re-Written to Justify Neo-Liberal Capitalism, Anthem, London.

Collier, P., and A. Hoeffler (2004), "Greed and Grievances in Civil War", Oxford Economic Papers 56, pp. 563-596.

Curtin, P. D. (1969), The Atlantic Slave Trade. A Census, University of Wisconsin Press, Maddison, WI.

de HaAn, J., and J. E. Sturm (2000), "On the Relationship between Economic Freedom and Economic Growth", European Journal of Political Economy, 16, pp. 215-241.

Easterly, W., and R. Levine (1997), “Africa’s Growth Tragedy: Policies and Ethnic Divisions", Quarterly Journal of Economics, 112, pp. 1203-1250.

Economic Freedom Index (Fraser Institute), URL: http://www.freetheworld. com/. 
Fanon, F. (1961), The Wretched of the Earth, from French, many editions, Penguin classics, London.

Freytag, A., and M. Paldam (2011), "Comparing Good and Bad Borrowing", P.t. paper for the European Public Choice Conference 2011.

Gallup, J.L., J.D. Sachs and A. D. Mellinger (1999), "Geography and Economic Development”, International Regional Science Review, 22, pp. 176-232.

Gourou, P. (1966, $4^{\text {th }}$ ed.), The Tropical World, from French 1953, Longman, London.

Grier, R. M. (1999), "Colonial Legacies and Economic Growth”, Public Choice, 98, pp. 317-335.

Gundlach, E., and M. Paldam (2009), "Farewell Primacy. The Political System and the Economy", European Journal of Political Economy, 25, pp.340-354.

Harden, B. (1991), Africa. Dispatches from a Fragile Continent, Harper Collins, London.

IBRD (World Bank) (1995), Bureaucrats as Managers. The Economics and Politics of Government Ownership, a World Bank policy research report, Oxford UP for the IBRD, New York.

Johnson, S., J. D. Ostry and A. Subramanian (2007), "The Prospects for Sustained Growth in Africa: Benchmarking the Constraints", NBER Working Paper 13120.

Jones, C. I. (2002, $2^{\text {nd }}$ ed.), Introduction to Economic Growth, Norton, NY.

Jones, T. (1976), Ghana's First Republic: The Pursuit of the Political Kingdom, Methuen, London.

Kamarck, A.M. (1967), The Economics of African Development, Praeger, New York.

Killick, T. (1978), Development Economics in Action, Heinemann, London.

Killick, T. (ed.) (1995), The Flexible Economy. Routledge (for the odi), London.

Krueger, A. O. (1992), The Political Economy of Agricultural Pricing Policy, a World Bank Comparative Study, Johns Hopkins University Press, Baltimore, MD.

La Porta, R., F. Lopez-de-Silane, A. Shleifer and R. Vishny (1998), "The Quality of Government", Journal of Law, Economics, and Organization, 15, pp. 222-279.

Maddison, A. (2003), The World Economy: Historical Statistics, OECD, Paris, updated versions until February 2010 available from Maddison homepage, URL: http://www.ggdc.net/maddison/.

Naipaul, V.S. (1975), "A New King for the Congo", New York Review of Books, June 26, several republications. 
Nunn, N. (2008), “The Long-Term Effects of Africa's Slave Trades”, Quarterly Journal of Economics 123, pp. 139-176.

Paldam, M. (2002), "The Cross-Country Pattern of Corruption: Economics, Culture and the Seesaw Dynamics", European Journal of Political Economy, 18, pp. 215-240.

Paldam, M. (2003), "The Economic Freedom of Asian Tigers. An Essay on Controversy", European Journal of Political Economy, 19, 453-77

Paldam, M., and E. Gundlach (2011), "The Democratic Transition: A Study of the Causality between Income and the Gastil Democracy Index", European Journal of Development Research, doi:10.1057/ejdr.2010.66

Polity (INSCR, Center for Systemic Peace), URL: http://www.systemicpeace. org/inscr/inscr.htm.

PRIO (Peace Research Institute Oslo) conflict data, URL: http://www.prio.no/ CSCW/

PTS (Political Terror Scale), URL: http://www.politicalterrorscale.org/

Rodney, W. (1972), How Europe Underdeveloped Africa. Howard University Press, Washington DC.

Rodrik, D. (2005), "Growth Strategies", in Handbook of Economic Growth, Vol. $1 A$, P. Aghion and S. N. Durlauf (eds) (2005), pp.967-1014.

Roeder, P.G. (2001), "Ethnolinguistic Fractionalization (ELF) Indices, 1961 and 1985. Document and report the ELF-index", URL: http//:weber.ucsd. edul-proederlelf.htm.

Stiglitz, J.E. (2002), Globalization and its Discontents, Allan Lane, London.

UNCTAD (United Nations Conference on Trade and Development), statistics at URL: http://www.unctad.org.

WDI, World Development Indicators (World Bank), URL: http://databank. worldbank.org/ddp/home.do.

Williamson, J. (1997), “The Washington Consensus revisited”, followed by comments by F. Steward, B. Persaud and T. Yanaghara, in Economic and Social Development into the XXI Century, L. Emmerij (ed.), pp.48-80, Johns Hopkins UP for the Interamerican Development Bank, Washington DC. 
Appendix Table: The 44 Countries Included in the Analysis

\begin{tabular}{|c|c|c|c|c|c|c|c|}
\hline & \multirow[t]{2}{*}{ Countries } & \multicolumn{3}{|c|}{ Population in 1,000 inh. } & \multicolumn{3}{|c|}{ GDP per capita, i.e., gdp } \\
\hline & & 1950 & 2008 & Growth & 1950 & 2008 & Growth \\
\hline 1 & Angola & 4,118 & 12,531 & 1.94 & 1,052 & 1,684 & 0.82 \\
\hline 2 & Benin & 1,673 & 8,533 & 2.85 & 1,084 & 1,394 & 0.43 \\
\hline 3 & Botswana & 430 & 1,952 & 2.64 & 349 & 4,769 & 4.61 \\
\hline 4 & Burkina Faso & 4,376 & 15,265 & 2.18 & 474 & 1,063 & 1.40 \\
\hline 5 & Burundi & 2,363 & 8,691 & 2.27 & 360 & 479 & 0.49 \\
\hline 6 & Cameroon & 4,888 & 18,468 & 2.32 & 671 & 1,212 & 1.02 \\
\hline 7 & Cape Verde & 146 & 427 & 1.86 & 450 & 2,735 & 3.16 \\
\hline 8 & CAR & 1,260 & 4,444 & 2.20 & 772 & 536 & -0.63 \\
\hline 9 & Chad & 2,608 & 10,111 & 2.36 & 476 & 706 & 0.68 \\
\hline 10 & Comoro Islands & 148 & 732 & 2.79 & 560 & 549 & -0.03 \\
\hline 11 & Congo, $\mathrm{Br}$ & 826 & 3,905 & 2.71 & 1,198 & 2,159 & 1.02 \\
\hline 12 & Congo, $\mathrm{Ki}$ & 13,569 & 66,515 & 2.78 & 570 & 249 & -1.41 \\
\hline 13 & Côte d'Ivoire & 2,860 & 20,180 & 3.43 & 1,041 & 1,095 & 0.09 \\
\hline 14 & Djibouti & 60 & 506 & 3.74 & 1,500 & 1,254 & -0.31 \\
\hline 15 & Equatorial Guinea & 211 & 616 & 1.86 & 540 & 22,049 & 6.61 \\
\hline 16 & Ethiopia (\& Eritrea) & 21,577 & 88,047 & 2.45 & 390 & 867 & 1.39 \\
\hline 17 & Gabon & 416 & 1,486 & 2.22 & 3,108 & 3,811 & 0.35 \\
\hline 18 & Gambia & 271 & 1,735 & 3.25 & 607 & 1,043 & 0.94 \\
\hline 19 & Ghana & 5,297 & 23,383 & 2.59 & 1,122 & 1,650 & 0.67 \\
\hline 20 & Guinea & 2,586 & 9,807 & 2.33 & 303 & 628 & 1.26 \\
\hline 21 & Guinea Bissau & 573 & 1,503 & 1.68 & 289 & 617 & 1.31 \\
\hline 22 & Kenya & 6,121 & 37,954 & 3.20 & 651 & 1,098 & 0.91 \\
\hline 23 & Lesotho & 726 & 2,128 & 1.87 & 355 & 1,952 & 2.98 \\
\hline 24 & Liberia & 824 & 3,335 & 2.44 & 1,055 & 802 & -0.47 \\
\hline 25 & Madagascar & 4,620 & 20,043 & 2.56 & 951 & 730 & -0.46 \\
\hline 26 & Malawi & 2,817 & 13,932 & 2.79 & 324 & 744 & 1.44 \\
\hline 27 & Mali & 3,688 & 12,324 & 2.10 & 457 & 1,145 & 1.60 \\
\hline 28 & Mauritania & 1,006 & 3,055 & 1.93 & 464 & 1,299 & 1.79 \\
\hline 29 & Mozambique & 6,250 & 21,285 & 2.14 & 1,133 & 2,160 & 1.12 \\
\hline 30 & Namibia & 464 & 2,089 & 2.63 & 2,160 & 4,571 & 1.30 \\
\hline
\end{tabular}




\begin{tabular}{|c|c|c|c|c|c|c|c|}
\hline & \multirow[t]{2}{*}{ Countries } & \multicolumn{3}{|c|}{ Population in 1,000 inh. } & \multicolumn{3}{|c|}{ GDP per capita, i.e., gdp } \\
\hline & & 1950 & 2008 & Growth & 1950 & 2008 & Growth \\
\hline 31 & Niger & 3,271 & 14,752 & 2.63 & 617 & 514 & -0.31 \\
\hline 32 & Nigeria & 31,797 & 146,255 & 2.67 & 753 & 1,524 & 1.22 \\
\hline 33 & Rwanda & 2,439 & 10,186 & 2.49 & 547 & 1,020 & 1.08 \\
\hline 34 & São Tomé & 60 & 206 & 2.16 & 820 & 1,484 & 1.03 \\
\hline 35 & Senegal & 2,654 & 13,343 & 2.82 & 1,259 & 1,456 & 0.25 \\
\hline 36 & Sierra Leone & 2,087 & 6,295 & 1.92 & 656 & 686 & 0.08 \\
\hline 37 & Somalia & 2,438 & 9,559 & 2.38 & 1,057 & 978 & -0.13 \\
\hline 38 & Sudan & 8,051 & 40,218 & 2.81 & 821 & 1,524 & 1.07 \\
\hline 39 & Swaziland & 277 & 1,129 & 2.45 & 721 & 3,150 & 2.57 \\
\hline 40 & Tanzania & 7,935 & 40,213 & 2.84 & 424 & 744 & 0.98 \\
\hline 41 & Togo & 1,172 & 5,859 & 2.81 & 574 & 606 & 0.09 \\
\hline 42 & Uganda & 5,522 & 31,368 & 3.04 & 687 & 1,008 & 0.66 \\
\hline 43 & Zambia & 2,553 & 11,670 & 2.65 & 661 & 845 & 0.42 \\
\hline 44 & Zimbabwe & 2,853 & 11,350 & 2.41 & 701 & 779 & 0.18 \\
\hline
\end{tabular}

Note: Gdp data are in 1990 international Geary-Khamis \$. Data for Eritrea are missing. Growth is in \% p.a.

\section{SUMMARY}

During the last 60 years development in Sub-Sahara Africa has had three main phases - P1, P2 and P3 - divided by kinks in 1972 and in 1994. P1 and P3 had fairly satisfactory growth, but $\mathrm{P} 2$ had negative growth. This cyclical growth path has to be explained by variables with a similar path. A set of socio-economic variables representing 11 hypotheses is considered. Some of these hypotheses have been proposed to explain the low growth of Africa, while most are meant to explain the growth tragedy of $\mathrm{P} 2$. Most of the variables have paths with no relation to the cycle, but the path corresponds to the shifts in the dominating development strategy. At the end of P1 the main policy-package in Africa became the one of African socialism. It led to large scale rent seeking, inefficiency and economic regression. At the end of $\mathrm{P} 2$ policies were adjustment towards a more market based system and growth resumed. 